\title{
South-Russian and Siberian Frontier: Analogies and Specific Character
}

\author{
Liudmila V. Baeva* \\ Astrakhan State University \\ 20 a Tatishchev Str., Astrakhan, 414056, Russia
}

Received 17.01.2015, received in revised form 20.02.2015, accepted 16.04.2015

The article focuses on the development of the theory of Russian frontier, analysis of its main concepts and topical issues in the field of its practical application. The study is based on the methodology of $J$. Turner, the author of the American frontier conception. The article dwells upon the features of the frontiers of Siberia and Southern Russia, reveals their common features such as heterogeneity, vectorality, struggle for resources, religious conflicts, instability of boundaries, suburban position, lifestyle free from traditions, etc. The analysis of the history of the conquest of southern suburbs and Siberia results in the conclusions about the nature of the process of the development of Russian metropolis, the peculiarities of the process of colonization of surrounding regions. Special attention is paid to the study of "a frontier personality" defined as a personality open to new solutions, choices, and changes of places, highly sensitive to the new, mentally free, creative, having a syncretical vision of reality and devoid of traditional stereotypical behavior. Analysis of the history of frontiers shows that these areas still remain marginal and unregulated by the Center. In modern period this leads to a reverse reaction, formation of a frontier aimed at "opening up" of Russia by its neighbors ("opening up" of Central Asia by the countries of the Caucasus and Siberia by China).

Keywords: frontier, frontier typology, border zone, frontier personality, Siberian frontier, SouthRussian frontier, heterogeneity.

The research is supported by the grant of the Ministry of Education and Science of the Russian Federation. The research under state project No. 2014/414 is "Frontier Personality: Challenges and Risks of Intercultural Communications in Cross-Border Areas", project code- 392.

Research area: philosophy.

\section{Introduction}

Resettlement, migration, conquests have always been the factors causing significant changes in social dynamics. Borrowings, sharing the traditions, experience, religious beliefs, and knowledge resulted in the societies' intensive development not only due to internal processes but also because of external influence. Conflicts of different cultures in the process of large groups' resettlement led to their synthesis, enrichment as well as to frequent destruction, loss of a defeated opponent's certain achievements. The territories of the peoples, who fell under the others' influence, became a kind of frontier, a border zone. Since the processes of settlement on new lands were long-lasting and uneven, their frontiers were

(C) Siberian Federal University. All rights reserved

* Corresponding author E-mail address: baevaludmila@mail.ru 
rather conventional, moving, changing in both directions and influencing each party.

\section{Theoretical framework}

Frontier territories were given a research focus in the XIX century. F.J. Turner was one of the first to study the processes of the development of America by the English and French (Turner 1962). Since Turner's time the theory of frontier had been further developed in the works by his followers in different countries. They studied not only the opposition of "barbarism" and "civilization" but also the issues of conflicts, intersection and penetration of different cultures which are no less complicated. In Russia the problem of territories was given a research perspective of the theory of frontier in the 90 -s of the XX century. The most significant steps in this direction were taken by the researchers of the history of the development of Siberia which was regarded to be analogous to American frontier but with its specific character (Skobelev 2002, Tikhonov 2010, Zamiatina 1998, Zuev 1999). At the same time the application of frontier research methodology proved to be promising not only for the study of Siberia but for many other frontier regions of Russia despite their uniqueness and distinguishing feature. Basing on the researches by the colleagues, studying Siberian frontier, it is worth while making an attempt to compare it with South-Russian frontier which is not thoroughly studied yet but arousing the researchers' fair interest (Iakushenkov, Iakushenkova 2010, Romanova, Topchiev, Sarakaeva 2013).

\section{Methods}

First it should be noted that the term 'frontier' has varied semantics and, thus, requires a terminological clarification. Originally the word 'frontier' nominated the territory (border) between the lands, developed and undeveloped by western migrants. Modern scholars term the 'frontier' concept as a zone of moving boundaries in a broader sense. N.Iu. Zamiatina defines 'frontier' as a "zone of unstable balance" (Zamiatina 1998). For our part we base on our previously developed classification of frontier types in which civilizational, intercultural, interreligious, ethnic, technological, axiological, informational, military-political, and linguistic types are distinguished (Baeva 2014). It is worth while dwelling upon the two main frontier types important for our research. Civilizational frontier is a territory of a moving boundary between peoples of "civilization" and "savagery" ("barbarism") (in Morgan-Engels's terminology), that is the peoples at different stages of the development of material life aimed at populating new lands, "domestication" of the natives or forcing them out (up to their extermination). "Classic" frontier, described by F.J. Turner as the area between the white settlers from Europe and the Red Indians of America, serves an example of this. A special type of civilization frontier can be a resettlement one, the specificity of which is described by the researchers of the history of populating Siberia. Intercultural frontier is a border zone between the cultures of different types associated with their displacement, interpenetration and mutual influence on each other. The examples of this are the Europeans' penetration to China, India, leading to both westernization of the traditional culture of the East and easternization of the cultures of western or Eurasian type (Europe, Russia, the USA). The difference of this frontier type from civilization frontier is in the following: their cultures are of a relatively equal position in their development, achievements, potential, and resources. In modern world this frontier type plays the most significant role, being related to global cooperation, including the attempt of multiculturalism, the largest groups of migrants' integration in the space of the assimilating culture. 
This typology can be used in the study of the process of a territorial conquest, when a complex of all kinds of frontier simultaneously manifests itself due to the differences in culture, civilization, technology, religion, etc. However, there may be relationships with a dominating frontier type. Thus, the process of Islamization or Christianization implies the interreligious frontier type, technological or ethnic differences playing no significant role here.

Basing on the most essential features of frontier, it is worth while analyzing its peculiarities on the territories of two major Russian frontiers: the south of Russia and Siberia.

\section{Discussion}

The frontier's first distinctive feature is vectorality, aiming at travelling on new lands and subordination of one subject by the other (civilization frontier type). As a result, a border becomes a moving one and it accompanies such phenomena as territorial conquests, development of "wild" territories, resettlement, migration, etc. The southern region of Russia, the Lower Volga and the Caspian Sea regions often were the object of conquest by various peoples dwelling on these territories (Scythian and Sarmatian tribes, the Khazars, the Mongols, the Russians), who then permanently settled in these territories. As it is known the Russian borders advanced to the south in the XVI-XVII centuries after Ivan the Terrible had annexed the Kazan and later the Astrakhan khanates. From the XVII century the Russian lands, inhabited by the Tatars, the Nogai people and later the Kalmyks as well as the settled nomadic peoples from the times of the Golden Horde, were developed due to their settlement by the Cossacks, military and trading people. However, this process was not similar to the American version of the Europeans' penetration into the Wild West. It largely revealed the policy of maneuvering, diplomacy, peaceful penetration into new territories which clearly differed from the cities and settlements of Central Russia for a long time (and to the present day). The development of southern regions in the direction of the Caspian Sea dates back to the mid XVI century (the year of 1554 is the year of the Astrakhan khanate's formal annexation). The history of this issue serves an indicator of the absence of long-lasting oppositions and military conflicts here. In 1553 Abdurrahman Khan, ruling Astrakhan at that period, signed a contract with Ivan the Terrible. This was contrary to the interests of the Crimean khanate that conquered Astrakhan and enthroned Yamghurchi Khan. He broke the previous agreement and entered into new alliances with Turkey and the Crimea. Ivan the Terrible wanted to resolve the conflict peacefully but his ambassador was arrested and exiled. Such attitude resulted in the following: in 1554 Ivan the Terrible sent three groups of a thousand people each to Astrakhan. They were led by the voevode (commander of an army) Yuri Ivanovich Pronsky-Shemyakin and Prince Ignatii Veshnyakov. Yamghurchi Khan escaped, his troops were partially destroyed and partially captured. Dervish-Ali was enthroned. Having a preliminary agreement with Moscow, he took an oath of allegiance to the tsar, signed an agreement on duty-free fishing and tribute collection. The Streltsy and Cossacks stayed in the city to run it. As for the main military forces, they returned to Moscow. But the new governor Dervish-Ali played a double game and tried to sign agreements with Turkey and the Crimea again. Thus, Ivan the Terrible sent his army back to the city. In 1556 ataman Filimonov headed the Cossacks' detachment there. The Astrakhan khanate already knew about the defeat of Kazan and surrendered without resistance. The tsar of Astrakhan was considered to be a Moscow ruler, and the Russian voevodes ruled in the cities on his behalf. The Astrakhan khanate finally became a part of Russia. The Astrakhan khanate 
was annexed peacefully, though some military confrontations took place. This process was similar to the conquests of the territories of the Urals and Siberia.

In the autumn of 1557 the territory of presentday Bashkortostan, located in the basins of the rivers Belaya and Ufa, was annexed to Russia without a fight. From 1560 the eastern border of Russia ran along the Ural river, the southern (south-eastern) one - along the river Terek. The next stage of frontier expansion was the conquest of Siberia. The development of Siberia began from 1581 with Yermak's journey and formally completed in 1639 when the Cossacks reached the Pacific Ocean. But still taiga and tundra, which were the main territories of Siberia, were sparsely populated. Thus, frontier territory here had its specific character. The nature of conquering Siberia by Yermak's Cossacks as well as conquering the Kazan and Astrakhan khanates differed from the British conquests of the American Indians' lands: the opposition there was formed not by the peoples at the primitive level of development but by the armed soldiers with swords and chain armors, who had excellent riders' skills. The difference in the level of development of these two clashing civilizations was not as contrastive as in America. These conquests gave rise to the formation of Russia as the world's largest Eurasian state.

As it is known, the historian S.M. Solov'iev assigned the beginning of the Russian state's expansion process to the times of Ivan IV who annexed or started the annexation of the Kazan, Astrakhan and Siberian khanates. The researcher S. Skobelev points out that the process of annexing Siberia was due to the imperial practice of ruling the dependent peoples, which was previously specific for the Mongol-Tatars. The practice implied minimal intervention in internal affairs, support of internal self-government, providing protection from foreign enemies, non-interference in religion and absence (with rare exceptions) of direct violence at the period of Christianization, collection of rather small tribute. The basic principles of the MongolTatars' imperial administrative practice (along with some additions), widely used by the Russian autocracy in ruling the peoples of Siberia, existed till the early XX century (Skobelev 2002).

It is important to note that in the process of the Russian state formation the borders were expanded by joining the surrounding areas and assimilating the conquered non-indigenous Mongol-Tatars. The process of Russian land expansion was mostly bloodless for the civilian population; military actions mainly involved the troops of the khans. Therefore, the comparison of this process with that of colonization of America by the Americans, the French and especially the Spanish reveals significant differences, although the US researchers compare these processes with the formation of the colonies. Thus, the American historian M. Khodarkovsky interprets Russia's territorial growth in the XVI-XVIII centuries as a colonial expansion and, consequently, characterizes Russia as a colonial empire. He distinguishes the following components of the colonization process: 1) erection of defense lines with fortresses, garrisons and artillery and their gradual advancement to the south and south-east from the Oka river, a traditional natural boundary of medieval Russia; 2) the bureaucracy (scribes, officials, translators, etc.); 3) the colonists enforced by the government and competing for the land; 4) the Orthodox Church; 5) attractiveness of the residence in a rich and mighty power to the immigrants from the steppes (Khodarkovsky 2002). If these features are key ones in the description of the colonization process, this point of view should be agreed with. If these features are extended with those of depriving the local population of land and resources, violation of the local population's 
rights up to its extermination, colonization of the territories which had no geographical connection with the metropolis, being characteristic features of colonization of North and Central America, then the features of frontier territories and empires emerging on them will be more essential than common features. The domestic historians still discuss the issue of whether the conquest of Siberia was peaceful and bloodless or bore the signs of a military gain. They have extreme points of view which are described in details by A.S. Zuev in the article "The character of conquering Siberia in contemporary history" (Zuev 1999). He believes that a true analysis of events makes it hardly possible to characterize them as "peaceful conquering" even though there were no facts to evidence military clashes, confrontations and violence against the local population.

Focusing back on the comparison of southern and Siberian frontiers it is worth while mentioning a high degree of heterogeneity as a characteristic feature of these frontiers. A peculiar feature of southern Russia and Siberia is diversity of cultures, peoples and ethnic groups, historically developing in substantial proximity to each other and having moving boundaries. Such numerous ethnic groups as the Russians, the Kazakhs, the Tatars as well as a considerable number of the peoples of the Caucasus, who arrived in Russia both in pre-Soviet period and after the 90-s of the last century, historically inhabited the territories of southern Russia and the North Caspian Sea region and interacted there. The Russians constituted a minor population of Astrakhan province for a long time, since it became a part of Russia. Only in the XIX century they gained a dominant position as per their number. In fact, the southern region of Russia, the Lower Volga and the Caspian Sea regions became a meeting place for many peoples (more than 100 of them dwell here), major confessions (of three world religions), and a variety of cultural traditions. Historically this region was a border zone, a world with moving boundaries and highly dynamic social, political, and spiritual processes.

As for Siberian frontier, it also connects the territories inhabited by many ethnic groups with diverse cultural traditions. That continued the formation of Russia as a Eurasian country. Prior to its conquest the Siberian khanate was inhabited by the Siberian Tatars, the Khanty (the Ostyaks), the Mansi (the Voguls), the Trans-Ural Bashkirs, the Yakuts, and others. The peoples' integration within the territory of one state was a devastating blow on their unique culture, language, traditions which were lost never to return, on the one hand, but formed a new unity of the peoples, established their communication and favoured their consolidation, on the other hand.

Another important feature of the frontier is a high religious heterogeneity. It is also specific for South-Russian and Siberian frontiers. Historically in southern Russia these were Christianity (mainly Orthodoxy) and Islam which were the main competitors despite the presence of Buddhism and Judaism on these territories. Siberian frontier turned out to be a zone of intersection of Christianity and traditional pagan cults, displacement of which was similar to the missionary work in the Wild West in America. Traditionally Astrakhan land was a crossroads of religions. Its traditions rooted in Atil, the capital of Khazaria with Judaism as an official religion, and Sarai-Batu adherent to Islam. Being close to Buddhist Kalmykia it had been the region of religious tolerance for many centuries. After the Astrakhan province had joined Russia the influence of Christianity started growing which led to the construction of Orthodox churches and monasteries. However, there were no significant religious conflicts, involving violent methods of Christianization, here. This was largely due to historical traditions of a multinational region, on 
the one hand, and to the fact that the competing religions were equal in their importance and status (unlike Siberian frontier where Christianity was opposed to pagan beliefs), on the other hand.

Remoteness from the "center" is also important for the frontier. It implies a significant freedom, frequent deviations from the "standards" of cultural life peculiar for the "middle" lands, as well as lesser respect for the authority (compared to the central part of the country). I. P. Basalaeva terms this criterion as "a marginal ("suburban") geopolitical location" (Basalaeva 2012), noting that it affects such phenomena as "administrative powerlessness" and "rating of the political power". The south of Russia, and namely the Volga delta, had traditionally housed the escaped convicts, outcasts, lumpens, free traders, fishermen, etc. since tsarist times. It was a settlement of freemen. There was no serfdom here, people could hide from the city authorities and have a relatively independent life. This manifested itself even more clearly in Siberia. N. Iu. Zamiatina figuratively described this in her work "Settlement zone (frontier) and its image in American and Russian cultures": "On the edge of the inhabited territory in Russia and the USA there lived people made of good stuff. They were "pushed" from their country's traditional society by the extraordinary circumstances because of their immoderate ambitions or just breachy nature. These were desperate poor people like the Irish, chronically suffering from poor harvests, and the inhabitants of London "bottom"..., enterprising businessmen and adventurers. Foggy suburbs attracted neither American nor Russian sedate and decent citizens" (Zamiatina 1998). A peculiar phenomenon of the frontier is a "frontier personality", a personality open to new solutions, choices, ready to change places, highly sensitive to the new, mentally free, having creative and syncretical vision of reality, adventurous, intolerant to restrictions, strict regulation and organization of life. A personality's frontier specificity consists of a special "energy of a border zone" (J. Turner), when a human trusts mainly himself, demonstrates high individualism, strives for independence and focuses on getting benefits without long-term labor. Frontier is a territory with the predominant philosophy of the "spoils system", easy profits from activities of a special type (fields, gold mining), as well as of conquering new territories and enrichment. These personality traits manifest themselves in border territories in different parts of the earth. They are also characteristic for southern Russia where life was never strictly regulated or observant of the law. According to J. Turner, the influence of contacting cultures on each other was like "a virus" as it infected every culture and led to the borrowing of language, lifestyle, everyday life which are evident in the life of the peoples of southern Russia .

Availability of resources is another important feature of the frontier. They are always struggled for whether it is land, gold, oil, fish stocks, etc. R. Billington, for example, defines the frontier as "a geographical region... with underpopulation density and usually rich but poorly developed natural resources, giving an exceptional opportunity to improve the small proprietors' social and economic status" (Billington 1991). Frontier interests primarily manifest themselves in the desire to strengthen "the attacking pupulation's" economic situation. The conquest of the Indians of North and Central America, the peoples of Siberia, the Far East, and the Europeans' expeditions to Central Asia and Africa were due to the search for new wealth, resources, and sources of wealth. In Siberia these were fur, silver and gold, and later diamonds, timber, gas and oil fields. A specific geographical resource of the South-Russian region was a favorable location, and namely the access to the Caspian Sea. This military-political aspect played an important role for Russia. The current situation 
suggests the region's most important resource to be hydrocarbon reserves (gas, condensate, oil) with their decisive role not only for the economic development of the Caspian basin states but also for the main political forces of the world (according to $\mathrm{Z}$. Brzezinski, nowadays those, who own the Caspian sea, control the world).

At the end of the last century the Caspian Sea territory became a hotbed of political disputes, conflicts, discussions which were not settled in many respects. This was primarily due to the oil reserves found in the Caspian Sea as well as to a challenging situation of the formation of new post-Soviet states in the region. The absence of a legislative solution on the issue of the Caspian Sea status just aggravated the problem. Whereas in the Soviet period the Caspian Sea countries were close to certain agreements, the solution of the problem reached a deadlock after the formation of five states around the Caspian Sea with the state property redistribution process in four of them. At the Fourth Summit of the Caspian States the heads of five states came to the agreements that had been looked forward to for 18 years. These concerned geopolitical security, protection of biological resources, and the legal status of the Caspian Sea. The wordings on delineation of water bodies, seabed, subsoil, as well as on navigation and fishing regime were specified. The provisions stating that a larger part of the Caspian water area is in common use are of a great significance. The agreement legislated that only the military forces of the coast-line countries have the right to stay in the Caspian Sea, which is a fundamental principle providing stability and security. We hope that the concluded agreements will contribute to peace processes and ensure the security of this strategically important region.

\section{Conclusion}

Thus, frontier regions have their own specific features, such as heterogeneity, vectorality, intense struggle for resources, religious conflicts, instability of boundaries, marginal position, certain lifestyle devoid of traditions, etc. These factors contribute to the formation of frontiers as special unstable zones, the development of which does not usually lead to introducing order, following the traditions, strict observation of the law and general requirements. Despite open tolerant intercultural relations here these areas are still the areas of risk.

Modern globalization processes largely explain why the research of the frontier theory cannot be limited to the analysis of the previous years. At present the territory of Siberia is becoming an area of new frontier with regards to massive penetration of China (or rather the citizens of China) into the Russian territories beyond the Urals. South-Russian frontier is also going through a new stage of its history: there is an active migration of the peoples of the Caucasus and Central Asia to the Lower Volga region. Massive migration flows are changing Russia's borders today as well as its cultural, ethnic and religious image with regards not to the suburban areas but also the capital itself. This makes us start thinking about the fact that at present the whole country can face an unstable border situation.

\section{Acknowledgements}

We are grateful to the Ministry of Education and Science of the Russian Federation for the support of this research under state project No. 2014/414, the theme being "Frontier Personality: Challenges and Risks of Intercultural Communications in Cross-Border Areas", project code -392 . 


\section{References}

1. Baeva L.V. (2014). Tipologiia i problemy izucheniia iuzhno-rossiiskogo frontira [The typology and problems of studying the southern Russian frontier]. Science Journal of Volgograd State University, (2), 32-39.

2. Basalaeva I.P. (2012). Kriterii frontira: k postanovke problem [The criteria of frontier: statement of the problem], Teoriia i praktika obshhestvennogo razvitiia. Available at: http://www. teoria-practica.ru (accessed 20 February 2014)

3. Billington R.A. America's Frontier Heritage. Albuquerque: University of New Mexico Press, 1991.

4. Iakushenkov C.N., Iakushenkova O.S. (2010). Amerikanskii frontir i rossiiskie analogi v Povolzh'e i na Nizhnei Volge [American frontier and its analogues in the Volga and the Lower Volga region]. The Caspian region: politics, economics, culture, 1, 109-114.

5. Khodarkovsky M. Russia's Steppe Frontier: The Making of a Colonial Empire, 1500-1800. Bloomington, Indianapolis: Indiana University Press, 2002.

6. Panarina E.S. (2013). Mify i obrazy sibirskogo frontira [Myths and images of Siberian frontier]. Kul'turnaia i gumanitarnaia geografiia, 2 (1). Available at: http://www.gumgeo.ru/index.php/ gumgeo/article/view/60 (accessed 9 March 2014)

7. Romanova A.P., Topchiev M.S., Sarakaeva E.A. (2013). Mezhkul'turnye kommunikatsii na frontire i vne frontira (sravnitel'nyi analiz) [Intercultural communications at the frontier and beyond it]. The Caspian region: politics, economics, culture, 3 (36), 298-303.

8. Skobelev S. (2002). Demografiia kak politika. Korennoe naselenie Sibiri v sostave Rossiiskoi imperii i SSSR: dinamika chislennosti kak otrazhenie politiki tsentra [Demography as politics. Indigenous population of Siberia in the Russian Empire and the USSR: demographic dynamics as a reflection of the center's politics]. Ab Imperio, 2, 181-182.

9. Tikhonov A.A. (2010). Frontir Sibirskii i Amerikanskii: tochki zreniia [Siberian and American frontier: the points of view]. Materialy nauchno-prakticheskoi konferentsii "Vaganovskie chteniia 2010" [The Proceedings of Science and Research Conference "Vaganovskie chteniya-2010"]. Available at: http://samlib.ru/t/tihonov_za_graniy/frontirsibirskijiamerikanskijtochkizrenija.shtml (accessed 26 February 2014).

10. Turner F.J. The frontier in American history. N.Y.: Henry Holt and Company, 1962. 373 p.

11. Zamiatina N.Iu. (1998). Zona osvoeniia (frontir) i eie obraz v amerikanskoi i russkoi kul'turakh [Settlement zone (frontier) and its image in American and Russian cultures]. Obshchestvennye nauki i sovremennost, 5, 75-89.

12. Zuev A.S. Kharakter prisoedineniia Sibiri v noveishei otechestvennoi istoriografii [The character of conquering Siberia in contemporary history]. Evraziia: kul'turnoe nasledie drevnikh tsivilizatsii. Vyp. 1. Kul'turnyi kosmos Evrazii [Eurasia: the cultural heritage of ancient civilizations. Vol. 1. The cultural space of Eurasia]. Novosibirsk, 1999. 


\title{
Южнороссийский и Сибирский фронтир: аналогии и специфика
}

\author{
Л.В. Баева \\ Астраханский государственный университет \\ Россия, 414056, Астрахань, ул. Татищева, 20 a
}

Статья посвящена развитию теории российского фронтира, анализу понятийного аппарата и актуальных вопросов в области ее практического применения. В основе исследования лежит методология Дю. Тернера, создателя кониепиии американского фронтира. В статье рассматриваются особенности фронтиров Сибири и Юга России, выявляются их общие признаки, такие как гетерогенность, векторальность, борьба за ресурсы, конфессиональные противоречия, неустойчивость грании, окраинное положение, свободный от традиций образ жизни, и др. Анализ истории завоевания южных окраин и территории Сибири позволяет сделать выводы о характере проиесса развития российской метрополии, особенностях проиесса колонизачии прилегаютих регионов. Особое внимание уделено изучению «фронтирного человека», который характеризуется как личность, открытая для новых решений, выборов, перемены мест, отличающаяся высокой восприимчивостью нового, ментальной свободой, творческим, синкретическим видением реальности, отсутствием стереотипного традииионного поведения. Анализ истории фронтиров показывает, что эти территории во многом так и остаются маргинальными, неупорядоченными Центром. В современный период это приводит к обратной реакиии, формированию пограничья, направленного на «освоение» России ее соседями (странами Кавказа, Средней Азии на юге и Китая в Сибири).

Ключевые слова: фронтир, типология фронтира, пограничье, фронтирная личность, сибирский фронтир, южно-российский фронтир, гетерогенность.

Работа подготовлена приподдержкегранта Министерства образования инауки РФ госзадание № 2014/414 по теме. «Человек фронтира: вызовы и риски межкультурных коммуникаиий в условиях приграничных территорий», код проекта 392.

Научная спещиальность: 09.00.00 - философские науки. 